Maciej Krzywosz

Uniwersytet w Biatymstoku

\title{
The Miraculous Sensibility of Two Twentieth-Century Polish Visionaries: Servant of God Rozalia Celakówna and Sr. Wanda Boniszewska
}

This article analyzes the elements of the personal sensibility and miraculous religiosity of two twentieth-century Polish visionaries, Servant of God Rozalia Celakówna and Sr. Wanda Boniszewska. The analysis is broken down into three sections. The first section elaborates on the concept of miraculous religiosity, which Polish sociologists and ethnologists of religion define as openness to any kind of miraculous occurrence. The second section provides brief biographies of Rozalia Celakówna (1901-1944) and Sr. Wanda Boniszewska (1907-2003). The third section describes the miraculous events (revelations, stigmata, proven prophecies) that occurred in the lives of both visionaries. The conclusion demonstrates how both visionaries manifested elements of miraculous sensibility; however, because both women avoided spectacular miracles and focused on their relationship with Christ (and not Mary), they definitely surpassed the scope of this research.

Key words: female religiosity, miraculous sensibility, miracles, private revelations, Rozalia Celakówna, Wanda Boniszewska.

\section{Introduction}

On May 24, 2006, Artur Górski submitted to Republic of Poland's Sejm the draft of a resolution to recognize Jesus as the King of Poland. Although the project ceased, through the work of numerous 
enthronement movements, the Polish Conference of Catholic Bishops (not the Sejm) officially recognized Jesus Christ as the King of Poland on November 19, 2016 in Eagiewniki. This event would have never taken place if it were not for the Polish mystic and Servant of God Rozalia Celakówna's visions, which served as the source and beginning of the enthronement movement. ${ }^{1}$

According to her biographer, Sr. Wanda Boniszewska was "hidden stigmatist,"2 who served as a completely different model of religiosity. Her spiritual life did not have the same kind of social effects as Rozalia's revelations, but many people indicate that consciousness about Boniszewska continues to increase and that she will become an important and lasting spiritual figure from Poland's twentieth century history. ${ }^{3}$

The increasing role of women in social and religious life has been noted in the social sciences, including the field of sociology, which has conducted a number of studies on the different ways to understand the relationship between women and religion. For example, studies have already been conducted on the role of religion in the formation of female identity ${ }^{4}$ and on the influence of social change and modernization on women's religiosity. In this regard, the British sociologist Linda Woodhead sensibly argues that theories of secularization tend to explain the attitudes of British Christian men (and not Christian women) who leave Christianity. Needless to say, this oversight should be explored and explained. ${ }^{5}$ Marta Trzebiatowska and Steve Bruce made an attempt to explain this phenomenon in their book Why are Women More Religious Than Men? which was published in 2012.

In addition to increasing scientific studies on the different aspects of female religious life, more studies on the broadly understood subject of the miraculous have been conducted. Just over a decade ago, science

1 The question of whether Celakówna called only for the enthronement of the person of Jesus Christ or also His heart is not relevant to this article. Therefore, this issue will not be discussed here.

2 See J.Pryszmont, Ukryta stygmatyczka: Siostra Wanda Boniszewska, 1907-2003 (Szczecinek: Fundacja Nasza Przyszlość, 2003).

$3 \quad$ See M. Kindziuk, “Nowa święta w Kościele?,” Gość Niedzielny, no. 15 (2008): $22-23$.

4 See K. Leszczyńska, Płeć $w$ instytucje uwikłana: reprodukowanie wzorców kobiecości i męskości przez świeckie kobiety $i$ świeckich mężczyzn w organizacjach administracyjno-ewangelizacyjnych Kościoła rzymskokatolickiego w Polsce (Warszawa: Wydawnictwo Naukowe SCHOLAR, 2016). 
treated miracles as remnants from the past and revelations as mental illness. For example, Hildegard of Bingen's visions were interpreted clinically as ocular migraines. ${ }^{6}$ Similarly, writing for "Polityka" (Politics), the Polish psychologist Krystyna Skarżyńska described individuals who see apparitions as "delusional individuals [with authoritarian personalities] who clearly manifest mental disorders." ${ }^{\prime 7,8}$ Yet, a radical change is occurring in this trend. Until recently, the social sciences were not interested in studying miracles and revelations, and, if studied, these phenomena were reduced to psychopathological categories. Now, however, more and more research is being conducted on miracles and revelations. Even more, secular scholars are coming to the agreement that healthy individuals can have revelations. ${ }^{9}$

Given the increasing research on the broadly understood religiosity of women and growing interest in miracles, this article will examine Servant of God Rozalia Celakówna and Sr. Wanda Boniszewska's religiosity and miraculous sensibility (for the purpose of this article, these terms will be used interchangeably) from an empirical (not theological) point of view, using terms from sociology of religion and religious studies. Although the fields of mystical theology, theology of miracles, and theology of spirituality often examine these matters, this article will follow the principles of empirical science and treat private revelations as miracles, even though, according to theology, private revelations and miracles are distinct and have been otherwise studied and recognized as playing separate roles in the economy of salvation.

This article will proceed as follows: 1) Section I will present the concept of miraculous sensibility as it has developed in Poland; 2) Section II will provide short biographies of Rozalia Celakówna and Sr. Wanda Boniszewska, respectively; and 3) Section 3 will explain the specific features of Rozalia and Sr. Wanda's miraculous religiosity.

\section{The Concept of Miraculous Religiosity}

The concept of miraculous religiosity (initially understood as miraculous sensibility and consciousness) developed in the 1970s in an

$6 \quad$ See E. Pakszys and L. Sikorska, introduction to Duchowość i religijność kobiet dawnieji dziś, eds. E. Pakszys and L. Sikorska (Poznan: Wydawnictwo Fundacji Humaniora, 2000), 10.

$7 \quad$ K. Skarżyńska, “Wiara czyni cuda,” Polityka, no. 16 (April 19, 1986): 8.

8 Ibid.

$9 \quad$ See. R. Stark, "A Theory of Revelations," Journal for the Scientific Study of Religion, no. 2 (1999): 287-308. 
ethnographic environment that dealt with Polish religious culture. Unfortunately, the first document that presented this concept in 1976 could not be published for political reasons. ${ }^{10}$ It was not until 1989 -after the fall of Communism in Poland - that the text could be published. From the very beginning, the authors of the text rejected the question of whether miracles really do occur. Instead, they approached miracles just as they would social fact; therefore, they upheld that "every event explained in the simplest way by cause and effect, physical phenomenon and metaphysical delusion, etc., can be considered miraculous if, in the consciousness of a single individual and more or less of the community, it has been found to be such, and not a common phenomenon that can be fully explained." 11

Two methodological consequences result from the aforementioned and brief definition of "miracle," which has been adopted for the purposes of social science and not, obviously, theology. First, the definition stands as a research postulate and, second, it affirms that there are phenomena that religious institutions (the Church) have not determined as being miraculous, but that people and communities perceive as miraculous. Furthermore, it affirms that empirical explanations of events that are considered miraculous in no way minimize their wondrousness.

The authors then proceed to link this concept with religion and define a miracle as: "any positive and real (daily and ordinary) matters that a person has determined to be directly connected [...] with the intervention of God or a specific holy person" 12 as well as contemporary events that are considered miraculous by an individual or group. This article is concerned with the former-namely, the individual.

Olędzki returned to the topic of individual miraculous consciousness in another article in which he examined the topic in light of contemporary votive offerings. ${ }^{13}$ In the article, he examines the record of votive offerings housed in monastery of the Bernardine Cistercian monks of Warta in Sieradz, Poland, which reveals the prevalence of votives offered either in petition or in thanksgiving for favors received as well as the common occurrence of miraculous consciousness. Olędzki also pointed out that the faithful's gratitude to a particular saint for his or

10 See.A.Hemka and J.Olędzki, "Wrażliwość mirakularna,” Polska Sztuka Ludowa, $1^{\text {st }}$ ed., no. 1 (1990): 14 .

11 Ibid, 9.

12 Ibid.

13 J. Olędzki, "Świadomość mirakularna," Polska Sztuka Ludowa, no. 3 (1989): 147-157. 
her intercession in resolving many of their problems is the result of their own rational and thoughtful action. However, they also thank a supernatural power for receiving a place to live in a dorm or for a successful operation, and they perceive miraculous activity in these outcomes. ${ }^{14}$

Ethnologist and sociologists of religion ascribed to the first concept of miraculous religiosity-both individual and collective, and they developed this idea in subsequent years. ${ }^{15}$ Today, miraculous sensibility is characterized as:

1) Belief in the existence of innumerable non-ordinary and miraculous events. All forms of intervention of the sacred [...] are not strange; they are part of the normal order of the world.

2) A focus on the concrete, real, and tangible presence of the sacred in reality. [...] Miraculous events of a spectacular nature are valued most.

3) Connecting almost every positive event with the intervention of the sacred (i.e., with God's or-more often—the Mother of God's action).

4) [M]iraculous phenomena must take place in system of ideas according to which an individual has functioned up to that point. ${ }^{16}$

\section{Rozalia Celakówna and Wanda Boniszewska's Biographies}

\section{Rozalia Celakówna}

Rozalia Celakówna was born into a large peasant family on September 19, 1901 in Jachówka, near Maków Podhalański, Poland. ${ }^{17}$ Her

$14 \quad$ Ibid, 150-151.

15 One can refer to the following works: H. Czachowski, Cuda, wizjonerzy i pielgrzymi: Studium religijności mirakularnej końca XX wieku w Polsce (Warsaw: Oficyna Naukowa, 2003); A. Zieliński, Na straży prawdziwej wiary. Zjawiska cudowne w polskim katolicyzmieludowym (Cracow: Nomos, 2004); M. Krzywosz, Cuda w Polsce Ludowej: Studium przypadku prywatnego objawienia maryjnego $w$ Zabtudowie (Bialystok: Oddział IPN, 2016).

A. Zieliński, Na straży, 65 .

17 The following are a recommended biographies of Rozalia Celakówna: Władysław Kubik, Trudna droga: Rozalia Celakówna Apostotka Mitości objawionej w Sercu Jezusa (Cracow: Wydawnictwo WAM, 2014); Z. Dobrzycki and S. Szafraniec, Wielkie wezwanie Serca Jezusa do Narodu Polskiego: Rozalia Celakówna i Jej Misja (Cracow: Wydawnictwo WAM, 2007); B. Nagel, Mistyczka 
parents were happily married, and she received a thorough religious education. From her early childhood, Rozalia's spiritual life was shaped by the pious literature found in her family home, daily prayers recited with her family, and frequent participation in religious devotions. At the age of seven, Rozalia heard an inner voice for the first time, which her biographer Fr. Kubik interpreted as a mystical experience. ${ }^{18}$ After receiving her First Holy Communion three years later and then the Sacrament of Confirmation in 1917, Rozalia decided to make a private vow of chastity. ${ }^{19}$ She did this of her own accord and not based on the advice or recommendation of a confessor or spiritual director, since she did not have one at the time. During this phase of her spiritual life, Rozalia grew in her faith by reading the lives of the saints (e.g., St. Francis de Sales).

After Rozalia made her private vow of chastity, a new phase in her life began-namely, a crisis known as the "dark night" in mystical theology. During this period, she experienced "a variety of moral and physical sufferings," ${ }^{20}$ and she did not know how to realize her vocation. While she was deeply religious, she did not know whether she should enter religious life or remain in the world. The only thing that she knew for certain was that she should leave her family home in Jachówka, which she did in 1924, and move to Cracow. In Cracow, Rozalia continued to grow in her interior life and tried to seek her ultimate destiny. She continually vacillated between choosing religious life, to which her confessors and spiritual guides directed her, and life in the world.

In 1925, Rozalia began working as a nurse at St. Lazarus Hospital in Cracow. Initially, she worked in the surgical ward. However, later she tended to patients suffering from venereal diseases when she began to hear an inner voice that said, "My child, it is my will that you work in the hospital; it is the place that I have marked out for you." ${ }^{21}$ However, working in the venereal disease ward, which was filled with patients including and quite often prostitutes who led addictive, chaotic, and sexual lifestyles, was initially too difficult for the young woman who had made a vow of chastity. Therefore, Rozalia resigned from her job at the hospital and went to spend more than two months at the convent of

z Jahówki: Doświadczenie nocy ciemnej w życiu duchowym Stużebnicy Bożej Rozalii Celakówny (Cracow: Wydawnictwo Św. Stanisława BM, 2015).

18 W. Kubik, Trudna droga, 46.

19 Ibid, 43

$20 \quad$ Ibid, 61.

$21 \quad$ Ibid, 68. 
the Poor Clare nuns in Cracow. Due to a sudden decline in her health, however, Rozalia was forced to leave, and in 1928, she returned to her work at the hospital. Initially, she worked in the ophthalmology ward, and later, at her own request, she moved back to the venereal disease ward. She devotedly and dedicatedly cared for her patients, which greatly weakened her health. Despite Rozalia's heroic dedication to the sick and to other ordinary people, she was often misunderstood by her superiors and harassed by others.

In September 1944, Rozalia contracted a cold that quickly turned into angina. Although she was brought to the hospital, it was too late. Rozalia died on September 13, 1944, and from then on her reputation for holiness spread.

\section{Wanda Boniszewska}

Wanda Boniszewska was born in Nowa Kamionka, near Nowogródek in Wileńszczyźnie in $1907 .{ }^{22}$ She received her First Holy Communion in the church in Nowogrodek in 1918. She later recalled that it was "then that the Lord Jesus spoke to me in a clear voice. I was very pleased that my Most Beloved was in my soul." ${ }^{23}$ One year later, she began to experience pain in her hands and feet in the same places where Jesus was pierced with nails. ${ }^{24}$ At first, the wounds were invisible; later, however, they became visible.

In 1924, Wanda entered the Congregation of the Sisters of the Angels in Vilnius. The mission of this order (which did not wear the habit) was to help "priests [...] in their apostolic work and to remain with them in spiritual fellowship." 25 At first, Wanda was not received into the order. Nevertheless, she did not give up, and she made her final profession of vows in the church Kalwaria Wileńska in 1933. From 1933 onward, Wanda lived primarily in the congregation's house in Pryciuny. On Holy Thursday in 1934, visible stigmata appeared on Wanda's body. The wounds would continue to appear at different times for the rest of her life.

22 The following are recommended biographies of Sr. Wanda Boniszewska: J. Pryszmont, Ukryta stygmatyczka: Siostra Wanda Boniszewska, 1907-2003 (Szczecinek: Fundacja Nasza Przyszlość, 2003); and W. Boniszewska, Dziennik duszy: Ukryta przed światem (Warsaw: Edycja św. Pawła, 2016).

23 W. Boniszewska, Dziennik, 76.

24 M. Damazyn, “Analiza źródeł,” in Dziennik, 23.

25 M. Piątkowska, introduction to Dziennik, 5-6. 
After World War II ended and the borders of Poland were altered, Wanda decided to remain in the USSR. She, along with other religious sisters, was arrested and imprisoned in the prison hospital in Eukiszk due to her poor health. After her trial, she was sentenced to ten years of hard labor and transported to Wierchnieuralsk, where she was humiliated, abused, beaten, and tortured with electrical equipment. She was deliberately placed with female prisoners who were severely mentally ill. Despite these persecutions, she did not abandon her spiritual life. Rather, she treated her experiences as her purgatory, or even hell. Wanda's attitude positively influenced other prisoners, the prison hospital staff, and even the prison authorities.

In 1956, the nightmare ended with the beginning of the process of deStalinization, and Wanda was released from prison, rehabilitated, and returned to Poland during the second repatriation. At her confessor Fr. Czeslaw Barwicki's command, Wanda wrote her memoirs. In Poland, she lived in convents in Konstancin-Jeziorna and Częstochowa. She died on March 2, 2003, having been very discreet about her supernatural experiences.

\section{The Visionaries' Miraculous Religiosity}

The brief biographies above confirm that both Servant of God Rozalia Celakówna and Sr. Wanda Boniszewska were sensitive to the miraculous. Both of their lives were characterized by revelations and various miraculous events that they did not consider strange because they were part of their normal order of reality. Doctors examined the mental health of both Boniszewska and Celakówna. For example, a neurologist examined Celakówna in 1938 and stated that Rozalia "[...] sometimes hears voices and has visions of an inexplicable nature. These symptoms do not give me the impression that she is mentally ill." ${ }^{26}$ Likewise, in 1943, a Dr. Hryniewicz examined Sr. Wanda Boniszewska and concluded that "should be classified as a constitutional psychopath." He also noted, however, that "[i]n addition to all of her psychophysical reflexes and her contact with her surroundings, the obscurity of awareness that I observed was very superficial."27

Both visionaries acknowledged that they experienced private revelations. ${ }^{28}$ In both cases, their visions, which initially began as voices,

\footnotetext{
$26 \quad$ Z. Dobrzycki and S. Szafraniec, Wielkie wezwanie, 174.

27 Ibid.

28 See R. Pindel, Proroctwa nie lekceważcie, wszystko badajcie: Objawienia prywatne w świetle słowa Bożego (Cracow: Wydawnictwo M, 1998), 77-130.
} 
started very early in their childhood and lasted for the rest of their lives. Boniszewska described the following: "When Jesus spoke, He was always visible. I often encountered Him as a traveler; He would meet me in the woods, or I would find Him sitting. I immediately understood that it was Him, even though $\mathrm{He}$ appeared no different on the outside than any other young traveler in his prime. Only, there was something about Him that attracted me. Ordinarily I would never stop and talk to strangers, especially to men, but His holiness was magnetic, and my soul sensed it. [...] Other people could not see Him, and they would say, "Wanda is delirious." 29

In addition to apparitions of Jesus Christ, Wanda also had visions of Mary and the angels, especially her guardian angel. In 1936, she described her guardian angel as "an extremely sweet little girl or boy, with beautiful eyes and a completely modest disposition. Most often the angel would express my thoughts and declare my passage to Golgotha on the following day or hour." ${ }^{30}$ Boniszewska also had visions of demons that she believed to be the source of her suffering. In her visions, Satan "would appear in the form of a llama, dog, impassioned man, [...] or like angels." " 31 She described the torment in the following way: "He would assail me with a shoe. They [the demons] would start pushing me and kicking my legs. They would squeeze my wounded sides with their elbows (because in addition to the wounds, there are still ulcers on my sides). I felt a tremendous pain and suffocating tightness in my chest, and I couldn't breathe. They would spit their stinky saliva right into my eyes face, on the side of my head, or into my eyes. They would strike my body in places that were already aching, and then leave me." 32 Deceased sisters from Wanda's congregation also appeared to her. For example, she said that Mother Ludwika Dolinska "helped me guide the sisters, and sometimes she was so vivid that it was as if she were still alive on the earth." 33

Stigmata and ecstasies were among the miraculous events that Sr. Wanda Boniszewska experienced. The stigmata were the result of her intense spiritual life and occurred especially during the Easter season and on Good Friday. She underwent incredible suffering because of them. At first, Wanda experienced only pain without any visible manifestation of the wounds. Later, however, bleeding wounds began

\footnotetext{
$29 \quad$ M. Damazyn, “Analiza źródeł,” in Dziennik, 34.

$30 \quad$ Ibid, 35.

$31 \quad$ Ibid, 37.

$32 \quad$ Ibid, 37-38.

$33 \quad$ Ibid, 38.
} 
to develop. It was then that other people, including Wanda's religious superiors, discovered her stigmata. Her superiors consulted doctors about the situation, and the doctors determined that the phenomena were of natural origin. ${ }^{34}$ Despite the spectacular nature of the stigmata, Boniszewska concealed the wounds from the world.

In addition to the stigmata, Sr. Wanda Boniszewska also experienced ecstasies, which she called her "sweet relationship with [her] Beloved," 35 as well as miraculous events that occurred in her daily life. For example, in 1927 the sisters voted in order to decide whether Sr. Wanda should leave or remain in their order. They did so by placing either a black bean (vote to leave) or white bean (vote to remain) into a cup. When one of the sisters poured out the contents, all the beans were white, meaning that Sr. Wanda would remain in the order. This event was interpreted as miraculous because one sister said, "How is it possible? I know that I deliberately put a black bean into the cup, not a white one." ${ }^{36}$ According to Sr. Wanda herself, the outcome of the vote was the result of the prayer vigil she had kept all night in the chapel in Ostra Brama. ${ }^{37}$

Rozalia Celakówna also experienced various revelations that began in her early childhood. Initially, she heard interior voices, and they were Christocentric. For example, when she was seven years old she heard a voice say, "My child! Give me everything! Be mine! The world will never give you happiness. It will not satisfy your desires. Give yourself to me and you will find everything. I will never leave you." ${ }^{38}$ At other times, Rozalia experienced visions of Mary. Once, when Rozalia was a teenager, the Most Holy Virgin Mary appeared and, pointing to the cross, said: "this cross is intended for you." 39 Rozalia did not consider these events strange, but rather a natural part of reality.

Over time, Rozalia's initially very personal experiences began to take on a more elaborate visual form, which probably stemmed from what she read in the writings of the mystics as well as from the advice that she received from her competent spiritual directors. When Rozalia worked in the ward for venereal disease, she had visions of the

\footnotetext{
$34 \quad$ Ibid, 24.

35 S. Urbański, introduction to Dziennik, 12.

36 J. Pryszmont, Ukryta stygmatyczka, 41.

$37 \quad$ Ibid, 40.

$38 \quad$ W. Kubik, Trudna droga, 46.

$39 \quad$ B. Nagel, Mistyczka, 31.
} 
suffering Christ (Ecce Homo) and of Christ enthroned which eventually led to the formation of the enthronement movement years later.

In addition to the visions of Jesus and Mary, Rozalia also had visions of mystics such as St. Teresa of Avila and St. Therese of Lisieux. During one vision, St. Teresa of Avila told Rozalia: "Child! Do not adopt another spirituality. Even though you have not entered religious life, your spirituality is that of Carmel. The Lord Jesus will lead you according to His way to the summit of perfection, meaning by the way of the cross, which He Himself walked." 40

Rozalia's visions often appeared when she was experiencing, for example, doubts and discouragement. Once, when Rozalia was concerned whether the state of her spirit offended Jesus, St. Therese appeared to her and said, "When you wake up in the morning, make every effort to do everything-even the smallest action-for Jesus. Whatever you encounter during the day, continually offer it to Jesus. Enjoy, rejoice, and carry your cross for Jesus. When you fall, do not be discouraged and lose your inner peace, but with the greatest confidence go to Jesus and, like a child, ask for forgiveness. Tell Him everything openly, simply, and sincerely. Tell Him that you are so small, weak, and in need of His help and support." 41

Because Rozalia wanted to lead a hidden life, St. Joseph-the model of humility and hiddenness-also appeared to her. ${ }^{42}$ One day he revealed to her: "I will help you in all things. I will direct your whole life of prayer, which must be similar to the life in Nazareth - that is: prayer, work, and a life most carefully hidden both from yourself and others." ${ }^{43}$ Celakówna also experienced prophetic visions of the enthronement of Christ the King, the fate of Poland, and the outcome of the Second World War, as well as the prediction of her own death. ${ }^{44}$

\section{Conclusion}

There is no doubt that the two twentieth-century Polish visionaries mentioned above exhibit elements of miraculous sensibility. Their connections with miraculous events were stronger than those of ordinary people, who occasionally experience something extraordinary that can be interpreted religiously. In the case of Celakówna and Boniszewska,

\footnotetext{
$40 \quad$ Z. Dobrzycki and S. Szafraniec, Wielkie wezwanie, 67.

$41 \quad$ Ibid.

$42 \quad$ Ibid, 69.

43 Rozalia Celakówna, Pisma (Cracow: Wydawnictwo WAM, 2008), 230.

${ }_{44}$ See. Z. Dobrzycki and S. Szafraniec, Wielkie wezwanie, 107-116.
} 
miracles (revelations) were part of their daily reality. Boniszewska's biographer and friend Fr. Pryszmont noted that ecstatic states and visions occurred "simply, as if it were quite ordinary." 45

There are significant differences between Rozalia and Wanda's religious lives and the lives of other Polish visionaries, stigmatists, and ordinary believers who are sensitive to the miraculous. First and foremost, the two visionaries did not seek miraculous occurrences by force, nor did they excite themselves with spectacular miraculous events. In fact, their spiritual fathers recommended that they avoiding any experiences of this kind..$^{46}$ In addition, they did not attract or gather crowds of indiscriminate followers, which often occurs in cases of modern visionaries. For both visionaries, the miraculous events that they experienced arose from their senses and not spectacular manifestations of power.

While Boniszewska experienced the stigmata, which is undoubtedly a spectacular phenomenon, she asked God to hide the wounds from other people. ${ }^{47}$ And, when God did not hide them, she herself hid them from the world. Similarly, unlike many contemporary visionaries, Celakówna did not publicly reveal her visions and prophecies about the impending war; instead, she presented them only to her confessor, Fr. Dobrzycki. ${ }^{48}$

Another difference between Celakówna and Boniszewska and other visionaries is the distinct Christocentric features of their miraculous sensibility. In Poland, where Marian devotion is predominant (the ratio of Marian shrines to other shrines is $80 / 20^{49}$ ), Rozalia and Wanda's miraculous sensibility was directed toward Jesus. Mary undoubtedly appeared in their revelations, but her role was peripheral. The Christocentric character of the revelations of these two visionaries distinguishes their religious experiences from those of contemporary visionaries to whom Mary has appeared. Moreover, not only were the positive events in the lives of both visionaries connected with God's action, but so too were their many miseries, difficulties, and sufferings insofar as they were able to make religious sense of them.

45 J. Pryszmont, Ukryta stygmatyczka, 14.

$46 \quad$ Ibid, 26.

$47 \quad$ Ibid, 31 .

48 W. Kubik, “Życie Służebnicy Bożej Rozalii Celakówny,” Rozalia Celakówna: Pisma, 17.

49 See. A. Datko, "Chrześcijańskie miejsca pielgrzymkowe w Polsce," 1050 lat chrześcijaństwa w Polsce, eds. P. Ciecieląg, B. Łazowska, P. Łysoń, and W. Sadłoń (Warszawa: GUS and ISKK, 2016), 160. 
In conclusion, both visionaries were sensitive to the miraculous as evidenced by their openness to various events that the tradition of the Catholic Church would describe as miraculous and in their interpretation of all (good and bad) events as occurring because of God's action. On the other hand, both Rozalia and Wanda go beyond this perspective; for, they did not seek spectacular miracles and visions, and they focused primarily on their relationship with Christ, not Mary. Undoubtedly, this testifies to the fact that both visionaries surpassed the level of miraculous sensibility described in Polish religious culture by ethnographers and sociologists of religion.

\section{ELEMENTY INDYWIDUALNEJ WRAŻLIWOŚCI MIRAKULARNEJ POLSKICH XX-WIECZNYCH WIZJONEREK - NA PRZYKŁADZIE SŁUGI BOŻEJ ROZALII CELAKÓWNY I SIOSTRY WANDY BONISZEWSKIEJ}

Artykuł analizuje elementy indywidulanej wrażliwości, religijności mirakularnej polskich XX-wiecznych wizjonerek - Sługi Bożej Rozalii Celakówny i s. Wandy Boniszewskiej. Tekst składa się z trzech części. W pierwszej, przedstawiona jest koncepcja religijności mirakularnej, wypracowana przez polskich socjologów i etnologów religii, rozumiana jako otwarcie na wszelkiego rodzaju zdarzenia cudowne.W części drugiej, zostały krótko ukazane biografie bohaterek tekstu, tj. Rozalii Celakówny (1901-1944) i Wandy Boniszewskiej (1907-2003). W części trzeciej, opisano zdarzenia cudowne (objawienia, stygmaty, sprawdzone proroctwa), których doświadczyły w swym życiu Celakówna i Boniszewska. W podsumowaniu wykazano, że u obu wizjonerek występują elementy wrażliwości mirakularnej, ale poprzez unikanie spektakularnych cudów oraz skupianie się na relacji z Chrystusem, a nie Maryją, zdecydowanie tę perspektywę badawczą przekraczają.

Słowa kluczowe: religijność kobiet, wrażliwość mirakularna, religijność mirakularna, cuda, objawienia prywatne, Rozalia Celakówna, Wanda Boniszewska.

\section{Bibliography:}

1. Boniszewska, W. Dziennik duszy: Ukryta przed światem. Warsaw: Edycja Św. Pawła, 2016.

2. Celakówna, R. Rozalia Celakówna: Pisma. Cracow: Wydawnictwo WAM, 2008.

3. Czachowski, H. "Współczesne objawienia maryjne-religijność ludowa pomiędzy magią a teologią." Studia Etnologiczne i Antropologiczne 3 (1999): 201-210. 
4. Damazyn, M. "Analiza źródeł," in Dziennik duszy: Ukryta przed światem." Warsaw: Edycja Św. Pawła, 2016, 15-45.

5. Dobrzycki, Z., and S. Szafraniec. Wielkie wezwanie Serca Jezusa do Narodu Polskiego: Rozalia Celakówna i jej misja. Cracow: Wydawnictwo WAM, 2007.

6. Hemka, A., and J. Olędzki. "Wrażliwość mirakularna." Polska Sztuka Ludowa, no. 1 (1990): 8-14.

7. Olędzki, J. "Świadomość mirakularna." Polska Sztuka Ludowa, nr. 3 (1989): 147-157.

8. Kubik, W. "Życie Służebnicy Bożej Rozalii Celakówny.” In Rozalia Celakówna: Pisma. Cracow: Wydawnictwo WAM, 2008, 9-19.

Miscellanea

9. Kubik, W. Trudna droga: Rozalia Celakówna Apostołka Miłości objawionej w Sercu Jezusa. Cracow: Wydawnictwo WAM, 2014.

10. Kindziuk, M. "Nowa święta w Kościele?" Gość Niedzielny, nr. 15 (2008): 22-23.

11. Nagel, B. Mistyczka z Jahówki: Doświadczenie nocy ciemnej w życiu duchowym Stużebnicy Bożej Rozalii Celakówny. Cracow: Wydawnictwo Św. Stanisława BM, 2015.

12. Pindel, R. Proroctwa nie lekceważcie, wszystko badajcie: Objawienia prywatne w świetle stowa Bożego. Cracow: Wydawnictwo M, 1998.

13. Pryszmont, J. Ukryta stygmatyczka: Siostra Wanda Boniszewska, 1907-2003. Szczecinek: Fundacja Nasza Przyszlość 2003.

14. Urbański, S. Introduction to Dziennik duszy: Ukryta przed światem. Warsaw: Edycja Św. Pawła, 2016, 7-14. 